\title{
Potential distribution of the tiger shrimp Penaeus monodon (Decapoda: Penaeidae), an invasive species in the Atlantic Ocean
}

\author{
David Petatán-Ramírez ${ }^{1}$, Luis Hernández ${ }^{1 *}$, Edgar Eduardo Becerril-García ${ }^{2}$, \\ Penélope Berúmen-Solórzano ${ }^{3}$, Daniel Auliz-Ortiz ${ }^{4} \&$ Héctor Reyes-Bonilla $^{1}$ \\ 1. Universidad Autónoma de Baja California Sur, Laboratorio de Sistemas Arrecifales, Carretera al Sur Km 5.5, CP \\ 23080, La Paz, BCS, México; 1ghm@uabcs.mx, dpetatan@uabcs.mx, hreyes@uabcs.mx \\ 2. Pelagios Kakunjá A.C., Sinaloa 1540, CP 23070, La Paz, BCS, México; bg.ragde@gmail.com \\ 3. Universidad Veracruzana, Instituto de Ciencias Marinas y Pesquerías. Calle Independencia $N^{\circ} 30$, Col. Centro CP \\ 94290, Boca del Río, Veracruz, México; berumen.penelope@gmail.com \\ 4. Universidad Nacional Autónoma de México, Instituto de Investigaciones en Ecosistemas y Sustentabilidad, Antigua \\ Carretera a Pátzcuaro No. 8701, C.P. 58190, Morelia, Michoacán; auliz.d@gmail.com \\ * Correspondence
}

Received 19-VI-2019. Corrected 19-XI-2019. Accepted 21-I-2020.

\begin{abstract}
Introduction: Invasive species are considered the second cause of extinction of native species after habitat loss. The impacts of invasive species have serious economic implications since the presence of this type of species can result in a decrease in ecosystem services granted to humans. In marine systems, some human activities such as maritime transport and aquaculture have favored the dispersion of invasive species, especially those with commercial importance. This paper describes the potential distribution of the tiger shrimp, Penaeus monodon, an invasive species along the American Atlantic coast. Objective: To describe a potential distribution model of Penaeus monodon in the American Atlantic region and compare the environmental characteristics of this region with those of the Indo-Pacific original niche conditions. Methods: Using geographic and environmental data, we constructed and tested three models to determine the efficiency of MaxEnt v. 3.3 software in predicting new areas for the distribution of this invasive shrimp species. Geographic data were downloaded from such web sites as the Global Biodiversity Information Facility, the Ocean Biogeographic Information System, and the United States Geological Survey, as well from literature. Environmental data were downloaded from Bio-Oracle v2.0 data base. The three tested models were: 1) the first was created using only recordings of Penaeus monodon from the Indo-Pacific (its origin zone) and then projected to the Atlantic (native model); 2) the second was built using only recordings from the invaded area; the training and projection area of this model was the Atlantic (invasive model); 3) the third included recordings from both the Indo-Pacific and Atlantic regions, and the model was trained and projected jointly in both areas (complete model). We extracted the values of the three models for each tiger shrimp sightings in the invaded area; sightings with values $\geq 0.5$ were considered as valid prediction of occurrence of the species. Results: We found that the following variables explained $80 \%$ of species distribution: phosphates from the ocean surface, coastal type, chlorophyll $a$, and maximum bottom temperature. In terms of the models' ability to predict the occurrences reported in the Atlantic, results were as follows: Native model had a prediction index of $40 \%$; Invasive model was able to predict $81 \%$ of recordings; and complete model predicted $92 \%$ of total occurrences reported in the invaded area. Conclusions: Our findings suggest that based on the complete model, the countries where the tiger shrimp could establish itself are Mexico and Cuba. Continuous monitoring and conservation actions are relevant in the countries where this species is currently established, as well of those countries with potential for invasions.
\end{abstract}

Key words: biological invasions, invasive prediction, realized niche, environmental factors model, spatial modeling.

Petatán-Ramírez, D., Hernández, L., Becerril-García, E.E., Berúmen-Solórzano, P., AulizOrtiz D., \& Reyes-Bonilla, H. (2020). Potential distribution of the tiger shrimp Penaeus monodon (Decapoda: Penaeidae), an invasive species in the Atlantic Ocean. Revista de Biología Tropical, 68(1), 156-166. 
In marine ecosystems, certain human activities such as maritime transport and aquaculture, have favored the dispersion of invasive species (Johnson, Ricciardi, \& Carlton, 2001), mainly those of commercial interest (Bax, Williamson, Aguero, Gonzalez, \& Geeves, 2003). This is the case of the tiger shrimp Penaeus monodon (Fabricius, 1798), which is native to the Indian Ocean and Western Pacific but is currently catalogued as invasive in the American Atlantic region (FAO, 2018).

The tiger shrimp has several biological and ecological characteristics that allow to consider it as an invasive species with the potential to alter local marine communities. Some of these characteristics include a large body size (33 $\mathrm{cm}$ in length; $320 \mathrm{~g}$ weight) and high fecundity when compared with other native shrimps like Farfantepenaeus aztecus (Northern brown shrimp, FAO, 2018), which leads to competitive advantages of $P$. monodon with respect to this kind of species (Morán-Silva et al., 2017). Additionally, the tiger shrimp is a non-selective feeder that consumes a broad variety of prey, such as crabs, other shrimps, polychaetes, ophiuroids, mollusks, small fishes and occasionally, detritus. As an euryhaline species, the larvae of $P$. monodon enters to coastal lagoons and estuaries, remaining in those coastal environments until reaching the juvenile stage (Cawthorne, Beard, Davenport, \& Wickins, 1983; Dall, Hill, Rothlisberg, \& Sharples, 1990; Lutz et al., 2015), where potential competition for food with the larvae and juveniles of other shrimps can occur.

Due to its high fecundity, this shrimp is an attractive species for commercial interests (Wakida-Kusunoki, De Anda-Fuentes, \& López-Téllez, 2013). Indeed, production of tiger shrimp increased from 21000 tons in 1981 to 676000 tons in 2001 (FAO, 2018). This significant increase drew the attention of aquaculture farmers in areas of West Africa, the United States of America, and several countries in Latin America, which led to the granting of permits for its exploitation in countries such as Brazil, and Colombia (Rodríguez \& Suárez, 2001; Briggs, Funge-Smith, Subasinghe, \&
Phillips, 2005). However, these species have been reported as a vector of several viral diseases, including white spot syndrome, which could be spread to native shrimp species and, potentially, other decapods if potential invasions get to occur (Flegel, 1997).

Findings of free specimens of $P$. monodon in West Atlantic waters have occurred since 1988, when some 2000 individuals were accidentally released from aquaculture farms in South Carolina. Subsequently, recordings of tiger shrimp have been made in several locations through the Caribbean, and as far as Northern Brazil (Cintra, De Sá Paiva, Do Nascimento Botelho, \& De Araújo Silva, 2011; Giménez-Hurtado et al., 2014; AlfaroMontoya, Monge-Ortiz, Martínez-Fernández, \& Herrera-Quesada, 2015; Wakida-Kusunoki et al., 2016; Knott, Fuller, Benson, \& Neilson, 2018). Reports of catches of P. monodon in the U.S. have increased from a few dozens in 2008 to hundreds since 2011 (Knott et al., 2018), and this trend is expected to continue, since the species is already established in the Northern Gulf of Mexico (GM), Colombia, and Venezuela (Altuve, Marcano, Alió, \& BlancoRambla, 2008; Sandoval, Leal-Florez, Taborda, \& Vázquez, 2014; Fig. 1).

Despite the specific records available, the general patterns of distribution in the American Atlantic are unknown, and potential areas for invasions by tiger shrimp have not been identified. This kind of information would make it possible to determine the regions where tiger shrimp management measures need to be focused in order to mitigate possible impacts on native biota (Simberloff, Parker, \& Windle, 2005). One of the tools used to address this type of problem involves ecological niche models (ENM) that allow researchers to evaluate the potential colonization of a region by invasive species before this occurs (Peterson \& Vieglais, 2001). The geographical distribution of a species consists of all the localities where it can subsist. This is known as the species' ecological niche. Ecological niche models first estimate the area that the species can occupy based on the environmental variables of the 


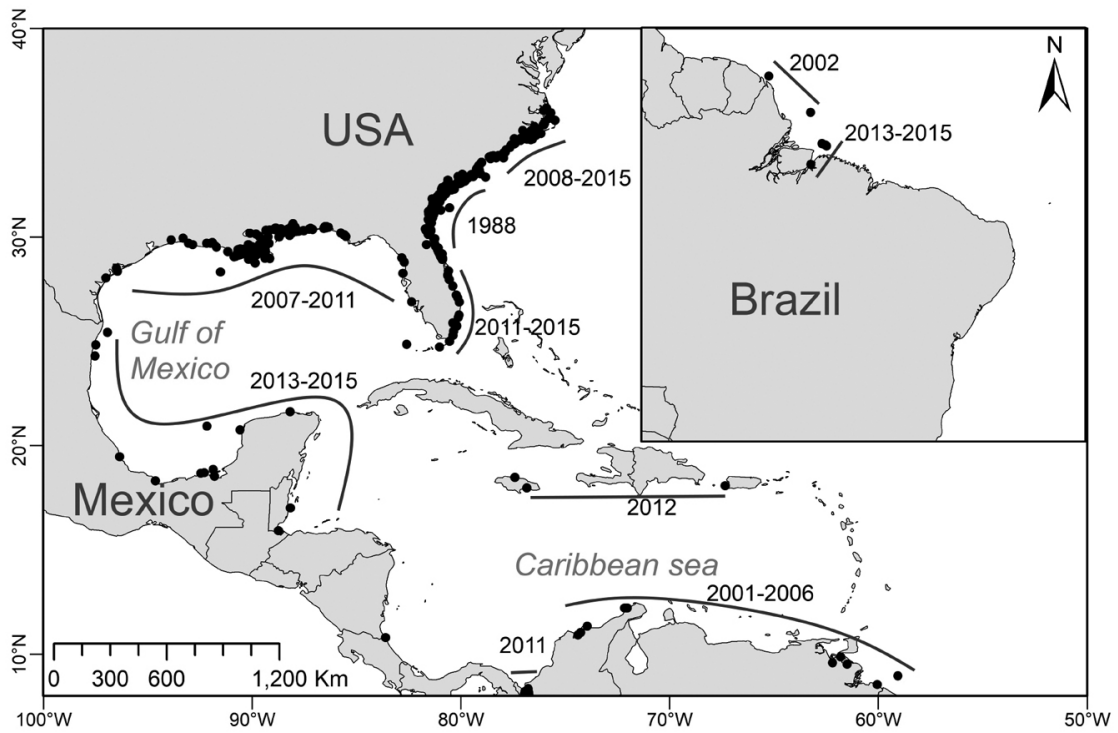

Fig. 1. Study area. Black dots represent recordings of Penaeus monodon in the American Atlantic Ocean. Grey lines show the period in which sightings of the species were registered.

places where sightings have been registered. These models then use these data to calculate the potential distribution that the species could have in a given region, by identifying the zones that comply with a combination of variables similar to those of the ecological niche determined by the model (Soberón \& Peterson, 2005). These methods have been used effectively to study invasive species of different taxonomic groups, including plants (Thuiller et al., 2005), amphibians (Ficetola, Thuiller, \& Miaud, 2007), birds (Da Silva, De Souza, Ribeiro, \& Machado, 2018), and fish (Kulhanek, Leung, \& Ricciardi, 2011).

The objectives of the present study were to: 1) estimate the geographic distribution of the tiger shrimp, P. monodon using ecological niche models; and 2) determine whether the ecological niches of native populations can explain the invasive patterns observed in the Atlantic. Our hypothesis was that there is an evolutionary fixation to the niches of species (Peterson \& Vieglais, 2001), and that the time of $P$. monodon invasion in the Atlantic Ocean is relatively short; hence, the ecological niche of this species has been conserved. If this is true, then it would be expected that the estimated ecological niche for Indo-Pacific populations would contain the ecological niche of Atlantic populations. In this way, the niche of Indo-Pacific populations could prove to be predictive of a high percentage of occurrences registered in the Atlantic.

\section{MATERIALS AND METHODS}

Occurrence data: Geographic recordings of tiger shrimp were obtained from the Global Biodiversity Information Facility (https://www. gbif.org/); the Ocean Biogeographic Information System (www.iobis.org/); the invasive species database of the United States Geological Survey (https://nas.er.usgs.gov/); and specialized literature. Repeated recordings and those within the same pixel [defined here as a $9 \times 9$ $\mathrm{km}$ quadrant (0.08333 latitude degrees)] were eliminated to avoid spatial autocorrelation of data. Occurrences data used were 365 from the Atlantic (invaded zone), and 173 in the IndoPacific (origin zone), and utilized to build and test the generated models.

Environmental variables: The data available in bio-oracle v2.0 were used. The variables 
used to explain tiger shrimp distribution were: temperature $\left({ }^{\circ} \mathrm{C}\right)$, salinity (UPS), chlorophyll $a$ $\left(\mathrm{mg} \cdot \mathrm{m}^{-3}\right)$, current speed $\left(\mathrm{m}^{-1}\right)$, nitrates $\left(\mathrm{mol} \cdot \mathrm{m}^{-}\right.$ $\left.{ }^{3}\right)$, phosphates $\left(\mathrm{mol} \cdot \mathrm{m}^{-3}\right)$, silicates $\left(\mathrm{mol} \cdot \mathrm{m}^{-3}\right)$, and dissolved oxygen $\left(\mathrm{mol} \cdot \mathrm{m}^{-3}\right)$. The maximum, minimum, and average values of each variable were considered from the surface, but we also included average data from the sea bottom for each one. Additionally, a standardized vegetation index raster (NDVI) was incorporated as an indicator of the dominant coastal ecosystem; referred to here as coastal type. The database, therefore, consisted of 33 environmental layers.

Because environmental variables tend to be highly correlated, we analyzed these variables to prevent multicollinearity with a variance inflation factor (VIF) using the "virtualspecies" package in R (R Core Team, 2018). We used the variables suggested by the removeCollinearity function in $\mathrm{R}$ using a cutoff at 0.7 . This function analyses and removes the collinearity among the environmental variables (Leroy et al., 2018).

Ecological niche modelling: To estimate the potential distribution of $P$. monodon, Maxent ver. 3.33 software was used (Phillips, Anderson, \& Shapire, 2006), as it allows researchers to use data on the presence-background modelling of a species to estimate the environmentally-favorable zones for the occurrence of that species (Elith et al., 2011).

Three types of models were designed to test the best prediction in the invaded area

1. the first was created using only recordings of P. monodon from the Indo-Pacific (its origin zone) and then projected to the Atlantic (hereinafter Mnat);

2. the second was built using only recordings from the invaded area; the training and projection area of this model was the Atlantic (hereinafter Minv);

3. the third included recordings from both the Indo-Pacific and Atlantic regions, and the model was trained and projected jointly in both areas (hereinafter Mcom).
Subsequently, the number of occurrences in the Atlantic that were correctly predicted by each model were quantified by estimating the habitat suitability index (HSI) value of each recording of the species' presence, and then extracting the HSI value of each model. We established that HSI values $\geq 0.5$ as a correctly predicted occurrence. If our hypothesis is correct, it would be expected that any model could predict the number of occurrences in a similar way. The habitat suitability index (HSI) was validated using 10000 pseudo-absences with the receiver operating characteristic (ROC) method and the area under the curve (AUC), with $75 \%$ of records for training and $25 \%$ randomly selected for testing the model. For each model we improved 30 replicates in Maxent as confidence data (mean and standard deviation). The AUC represents the probability that a random positive instance and a random negative instance are correctly classified; values higher than 0.8 in the AUC are considered as a good probability. In presence-only modelling, the technique is applied to distinguish presence from random occurrence, rather than presence from absence.

To determine the correspondence between the ecological niches of tiger shrimp populations in the Indo-Pacific and Atlantic, we use the framework proposed by Broennimann et al. (2012) in R software. We selected the principal component analysis to show the climatic space of each niche. Niche overlap estimations were based on Schoener's index (D value, Schoener, 1968; Warren, Glor, \& Turelli, 2008). Niche similarity of native to invaded area and viceversa were estimated based on 100 iterations to ensure that the null hypothesis can be rejected with high confidence (Broennimann et al., 2012).

\section{RESULTS}

Of the three models tested, the Mnat potential distribution model (Fig. 2A1) showed good performance $(0.94 \pm 0.006$ AUC) in terms of ascertaining the colonization of tiger shrimp in the U.S. from the coasts of Florida 
to North Carolina, as well as Texas. In the case of Mexico, the distribution area extended from the State of Tamaulipas to Campeche. According to this model, the Western coasts of Cuba has favorable conditions for the establishment of tiger shrimp, as do shores from Colombia to the Gulf of Venezuela, including areas near the Orinoco River estuary. At last, the potential area for the establishment of the tiger shrimp includes the Amazon River estuary and the Northern coast of Brazil (Fig. 2A2).

For the Minv model (Fig. 2B1), which used only recordings in the invaded zone, an adjustment of $0.94( \pm 0.004)$ of the AUC was obtained with a potential distribution that encompassed the coastal zone of Louisiana, Mississippi, Alabama, and Florida and the Atlantic coast from Florida to North Carolina. According to this model, only a few coastal lagoons in Mexico, Colombia, and Venezuela are potentially suitable habitats for tiger shrimp; while no areas of potential distribution were detected on the coasts of Brazil (Fig. 2B2).

Finally, the Mcom model (Fig. 2C1), which incorporates both native and invasive recordings, had an AUC setting of $0.96( \pm 0.006)$. This model shows a wide area of potential distribution, running from the state of North
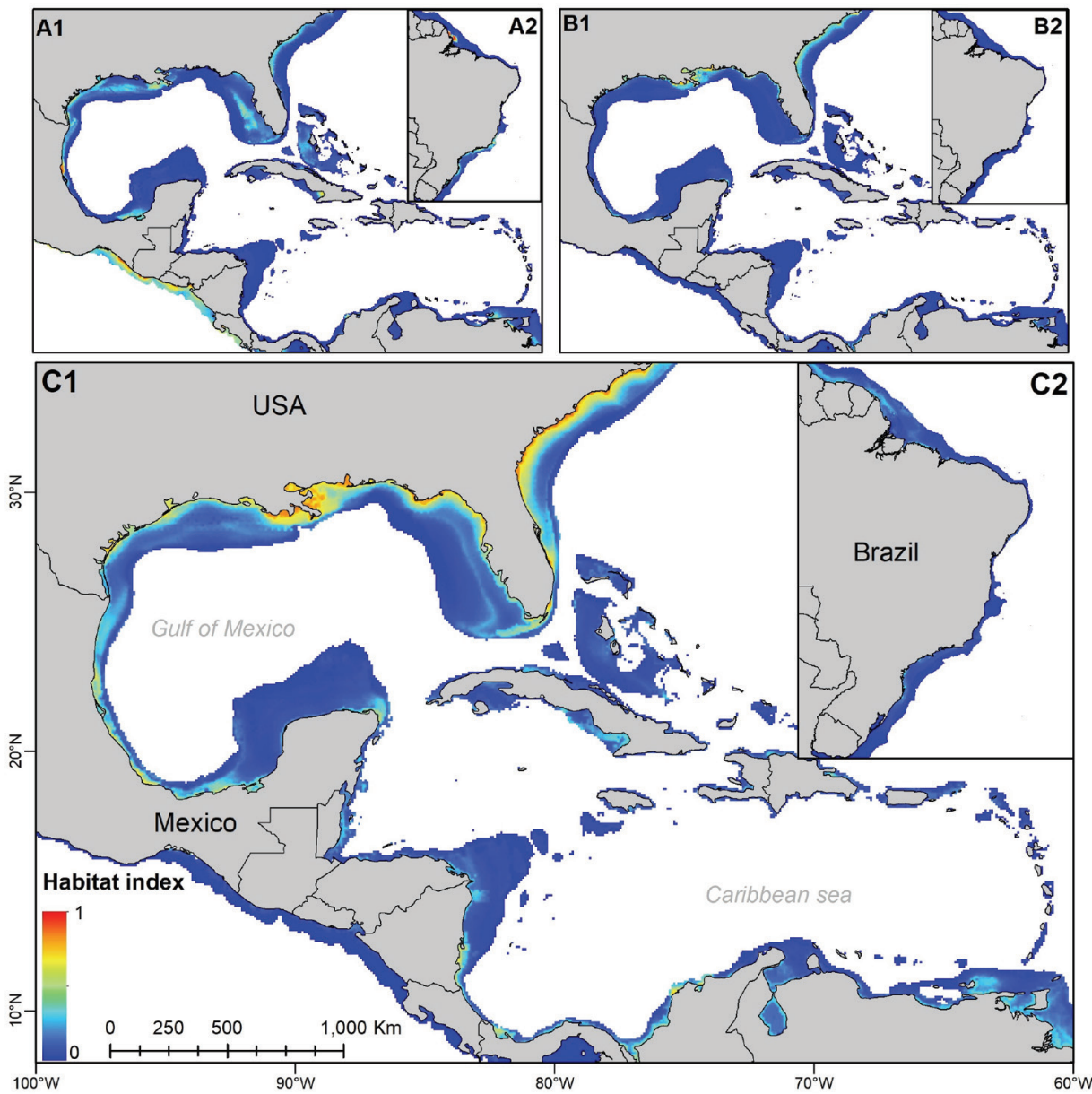

Fig. 2. Results of the modelling for Penaeus monodon: (A) Mnat, with only Indo-Pacific recordings and projections into the Atlantic; (B) Minv, using only recordings of invasions in the Atlantic; and (C) Mcom, using all known recordings (IndoPacific and Atlantic data). 
Carolina to Campeche, Mexico, with some localities on the coasts of Belize, Honduras, Nicaragua, Costa Rica, and Panama. Potential distribution is also shown for Guacanayabo Bay, Cuba. Along the South American coasts, potential distribution was found in Colombia and, especially, in the Orinoco River estuary.
In the case of Brazil, the Amazon River estuary is another potential area for the distribution of tiger shrimp (Fig. 2C2).

In terms of the models' ability to predict the occurrences reported in the Atlantic, results were as follows: Mnat, had a prediction index of $40 \%$; Minv was able to predict

TABLE 1

Contribution of the environmental variables to the best performing model (Mcom) with the Atlantic and Indo-Pacific recordings of Penaeus monodon

\begin{tabular}{|c|c|c|c|}
\hline Environmental variables & $\begin{array}{l}\text { Contribution to } \\
\text { model (\%) }\end{array}$ & $\begin{array}{c}\text { Recordings in the } \\
\text { Indo-Pacific }(\text { mean } \pm \mathrm{SD})\end{array}$ & $\begin{array}{l}\text { Recordings in the } \\
\text { Atlantic (mean } \pm \mathrm{SD})\end{array}$ \\
\hline Maximum superficial phosphate & 35.1 & $0.10 \pm 0.15$ & $0.04 \pm 0.10$ \\
\hline Coastal type (NDVI) & 19.8 & $0.27 \pm 0.21$ & $0.29 \pm 0.20$ \\
\hline Minimum superficial chlorophyll-a & 14.5 & $0.13 \pm 0.08$ & $0.14 \pm 0.08$ \\
\hline Maximum bottom temperature & 11.5 & $23.70 \pm 3.99$ & $23.39 \pm 3.54$ \\
\hline Minimum superficial nitrate & 5.9 & $1.83 \pm 4.03$ & $2.34 \pm 4.43$ \\
\hline Mean superficial salinity & 2.1 & $33.03 \pm 4.16$ & $32.61 \pm 4.60$ \\
\hline Maximum superficial current speed & 1.9 & $0.30 \pm 0.23$ & $0.29 \pm 0.20$ \\
\hline Mean bottom dissolved oxygen & 1.8 & $212.75 \pm 20.92$ & $216.33 \pm 20.69$ \\
\hline Minimum superficial salinity & 1.7 & $29.96 \pm 6.76$ & $29.2 \pm 7.42$ \\
\hline Mean superficial dissolved oxygen & 1.3 & $216.28 \pm 11.03$ & $218.91 \pm 10.56$ \\
\hline Mean bottom salinity & 1.1 & $34.07 \pm 3.27$ & $33.87 \pm 3.66$ \\
\hline Mean bottom chlorophyll-a & 0.8 & $0.36 \pm 0.22$ & $0.40 \pm 0.23$ \\
\hline Maximum superficial temperature & 0.7 & $29.56 \pm 1.23$ & $29.59 \pm 0.94$ \\
\hline Mean bottom silicate & 0.6 & $11.09 \pm 14.77$ & $12.02 \pm 15.41$ \\
\hline Mean bottom current speed & 0.4 & $0.11 \pm 0.18$ & $0.10 \pm 0.16$ \\
\hline Mean superficial chlorophyll-a & 0.4 & $0.37 \pm 0.24$ & $0.40 \pm 0.25$ \\
\hline Minimum superficial dissolved oxygen & 0.2 & $198.35 \pm 4.90$ & $199.14 \pm 4.03$ \\
\hline Minimum superficial current speed & 0.1 & $0.23 \pm 0.20$ & $0.20 \pm 0.17$ \\
\hline Maximum superficial phosphate & 35.1 & $0.10 \pm 0.15$ & $0.04 \pm 0.10$ \\
\hline Coastal type (NDVI) & 19.8 & $0.27 \pm 0.21$ & $0.29 \pm 0.20$ \\
\hline Minimum superficial chlorophyll-a & 14.5 & $0.13 \pm 0.08$ & $0.14 \pm 0.08$ \\
\hline Maximum bottom temperature & 11.5 & $23.70 \pm 3.99$ & $23.39 \pm 3.54$ \\
\hline Minimum superficial nitrate & 5.9 & $1.83 \pm 4.03$ & $2.34 \pm 4.43$ \\
\hline Mean superficial salinity & 2.1 & $33.03 \pm 4.16$ & $32.61 \pm 4.60$ \\
\hline Maximum superficial current speed & 1.9 & $0.30 \pm 0.23$ & $0.29 \pm 0.20$ \\
\hline Mean bottom dissolved oxygen & 1.8 & $212.75 \pm 20.92$ & $216.33 \pm 20.69$ \\
\hline Minimum superficial salinity & 1.7 & $29.96 \pm 6.76$ & $29.2 \pm 7.42$ \\
\hline Mean superficial dissolved oxygen & 1.3 & $216.28 \pm 11.03$ & $218.91 \pm 10.56$ \\
\hline Mean bottom salinity & 1.1 & $34.07 \pm 3.27$ & $33.87 \pm 3.66$ \\
\hline Mean bottom chlorophyll-a & 0.8 & $0.36 \pm 0.22$ & $0.40 \pm 0.23$ \\
\hline Maximum superficial temperature & 0.7 & $29.56 \pm 1.23$ & $29.59 \pm 0.94$ \\
\hline Mean bottom silicate & 0.6 & $11.09 \pm 14.77$ & $12.02 \pm 15.41$ \\
\hline Mean bottom current speed & 0.4 & $0.11 \pm 0.18$ & $0.10 \pm 0.16$ \\
\hline Mean superficial chlorophyll-a & 0.4 & $0.37 \pm 0.24$ & $0.40 \pm 0.25$ \\
\hline Minimum superficial dissolved oxygen & 0.2 & $198.35 \pm 4.90$ & $199.14 \pm 4.03$ \\
\hline Minimum superficial current speed & 0.1 & $0.23 \pm 0.20$ & $0.20 \pm 0.17$ \\
\hline
\end{tabular}


$81 \%$ of recordings; and Mcom predicted $92 \%$ of total occurrences reported in the invaded area. Data indicate that the variables phosphate, coastal type, chlorophyll, and temperature explained around $77 \%$ of the distribution of tiger shrimp in the Atlantic Ocean (Table 1).
Principal component analysis (Fig. 3A, Fig. 3B), meanwhile, showed differences between the natural niches of the Indo-Pacific population and the Atlantic Ocean invasive population, with the latter being more extensive in the number of variables and geographic area.
A PCA-env - Atlantic niche

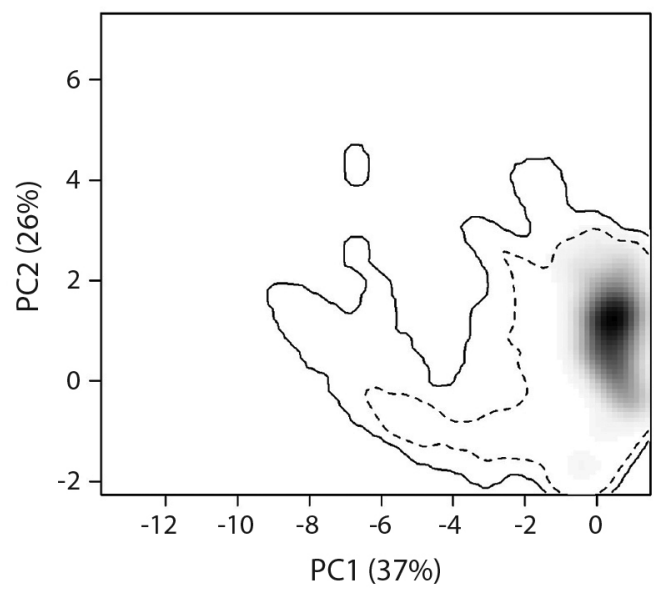

\section{B PCA-env - Indo Pacific niche}

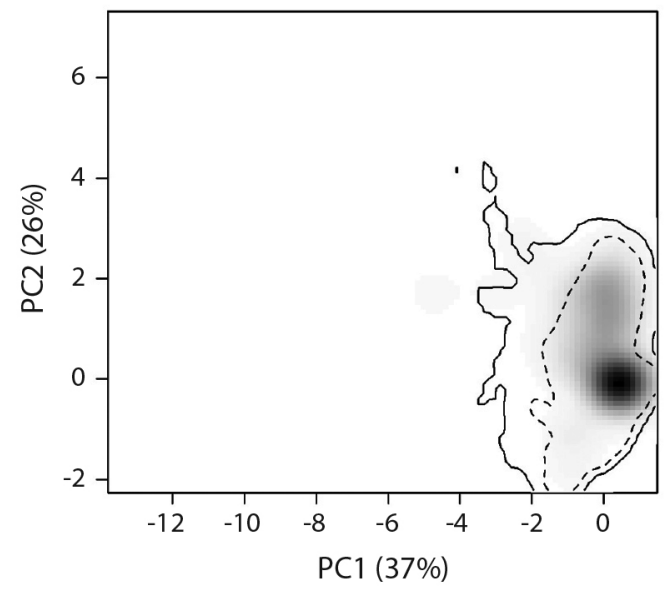

C Equivalency

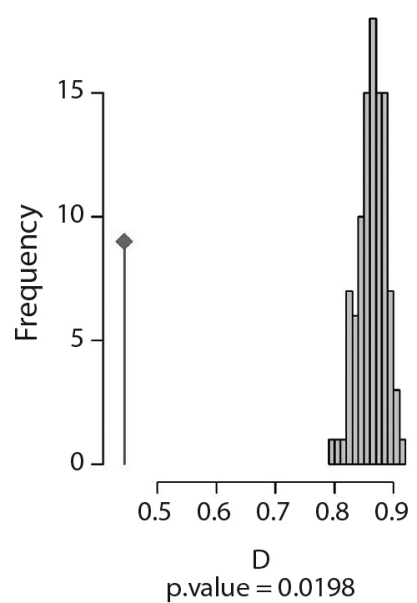

D Similarity IND -> ATL

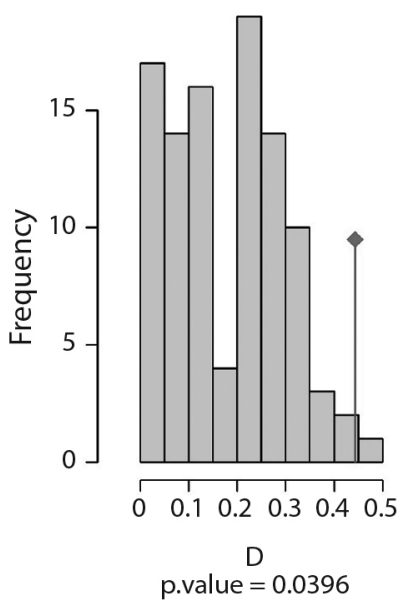

E Similarity ATL -> IND

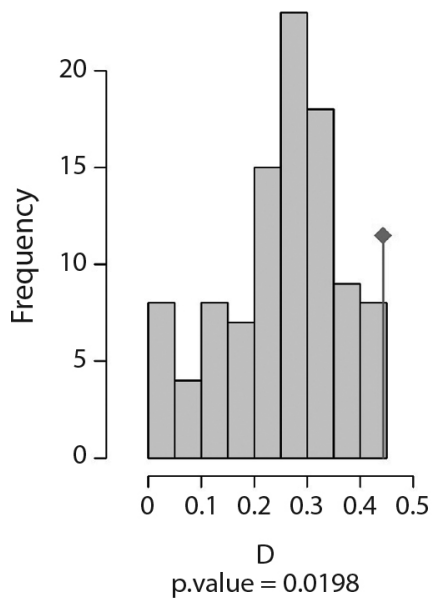

Fig. 3. Niche representation of Penaeus monodon in climatic space - example of a principal component analysis (PCA-env). Panels (A) and (B) represent the niche of the species along the two first axes of the PCA in the Indo-Pacific native (IND) and Atlantic Ocean invaded range (ALT), respectively. Grey shading shows the density of the occurrences of the species by cell. The solid and dashed contour lines illustrate, respectively, $100 \%$ and $50 \%$ of the available (background) environment. Histograms $(C)-(E)$ show the observed niche overlap $D(D=0.429)$ between the two ranges (bars with a diamond) and simulated niche overlaps (grey bars) on which tests of niche equivalency (C), niche similarity of IND to ATL (D), and niche similarity of ATL to IND (E) were calculated from 100 iterations. 


\section{DISCUSSION}

The models applied showed that there is no evidence of niche conservation between IndoPacific and Atlantic tiger shrimp populations, because the characteristics of the ecological niche of native populations did not successfully account for the occurrences in the invasion zone; in contrast to the data on the ecological niche of both joint populations. In addition, the ecological niche comparisons (Fig. 3A, Fig. 3B) suggest that there is a niche shift in the invasive population (Broennimann \& Guisan, 2008) and, the Atlantic tiger shrimp population is exposed to environmental conditions that differ from those of its origin zone (Fig. 3D, Fig. 3E, Table 1). This means that $P$. monodon is expanding its niche, a finding that could explain why this invader has such an extensive distribution along the American Atlantic coast.

The concept of niche displacement refers to the ability of some species to change the average position of their ecological niche (niche centroid) in the environmental space (Guisan, Petitpierre, Broennimann, Daehler, \& Kueffer, 2014). In other words, a change in the stocking conditions occupied by a species. This phenomenon seems evident for the tiger shrimp in the Atlantic, perhaps due to rapid adaptive changes to new environmental conditions, as area compared in figure $3 a$ and $b$, that differ from those of its native region (Bock et al., 2015; Turner, Fréville, \& Rieseberg, 2015) (Fig. 3A, Fig. 3B). These findings could also be interpreted as a difference between the fundamental niche and the real niche due to biological interactions like niche competition (Tingley, Vallinoto, Sequeira, \& Kearney, 2014), a mechanism that has been used to explain the absence of niche conservation in invasive species (Broennimann \& Guisan, 2008; Turner et al., 2015; Da Silva et al., 2018). If it is true that the tiger shrimp undergoes niche displacement in the invaded environment, this could have strong implications, since it would favor the establishment of populations in additional habitats, thus increasing its invasive potential. In this regard, future research should evaluate the biological performance of tiger shrimp in invasive areas, especially because changes in the phenology of some invasive species in the invaded environment have been documented (Turner et al., 2015). Clearly, our models generated distinct results, and briefly 1) Mnat, which used IndoPacific recordings exclusively to determine projections for the Atlantic, predicted only $40 \%$ of the invasion records; thus refuting our hypothesis that $P$. monodon's Indo-Pacific niche would predict the niche for the Atlantic populations, as a conservative niche (Peterson \& Vieglais, 2001). 2) Minv, which utilized only invasion records, was only able to forecast a high probability of occurrence along U.S. coasts, and a very low probability for the rest of the study area. This could be due to the large number of recordings from the U.S., which allowed it to predict $81 \%$ of occurrences in the Atlantic. This models' deficiency in terms of predicting invasion areas in Latin America could be due to the scarce recordings there. Although the presence of the species is known in several localities in that area, there is currently little documented evidence of these findings (Altuve et al., 2008; Morán-Silva et al., 2017). 3) Mcom, which combined all recordings of $P$. monodon, resolved the deficiencies of the Minv and Mnat models, since it had a better performance, which predicted 92 $\%$ of the occurrences of this species. Also, this model encompassed the entire niche known for this species by including both native and invasion recordings.

Since invasive species are able to acclimate and adapt to environmental conditions distinct from those of their original area (Turner et al., 2015), constructing and testing models of potential distribution using only recordings from the original localities of the species to project invasions does not generate optimum results, as evidenced by the present case. In this regard, the ecological niches occupied by tiger shrimp in the Indo-Pacific and Atlantic are different, as the Atlantic invasion zone is wider and only slightly overlaps the ecological niche that this species occupies in its original area (Fig. 3D, Fig. 3E). When all recordings were used, the entire niche known for the species was identified and found to account for all 
the variation. Thus, the Mcom model had the best performance.

Based on the Mcom model, the countries where the tiger shrimp could establish itself are Mexico and Cuba. It is possible that the organisms collected in Venezuela and Guyana were dragged there from Brazil by water currents (Duncan, Schladow, \& Williams, 1982). Therefore, including the U.S. coasts, there are two invasive sources of P. monodon in the Atlantic, so its dispersion into the Gulf of Mexico and the Caribbean Sea could occur through the coastal transport of eggs and larvae following the flows mentioned by Duncan et al. (1982).

In addition to competing for space and food with other species, the economic impact that could be caused by the invasion of $P$. monodon in the Atlantic varies according to the region. In Colombia, for example, it could threaten the Southern withe shrimp (Litopenaeus schmitti) (Sandoval et al., 2014), while in Venezuela the fisheries of five shrimp species could be affected: white shrimp L. schmitti, brown shrimp Farfantepenaeus subtilis, pink spotted shrimp $F$. brasiliensis, pink shrimp $F$. notialis, and titi shrimp Xiphopenaeus kroyeri (Aguado \& Sayegh, 2007). If invasions occur in Mexico, populations of brown shrimp $F$. aztecus, pink shrimp $F$. duorarum, white shrimp L. setiferus, pink shrimp F. brasiliensis, and rock shrimp Sicyonia brevirostris (MoránSilva et al., 2017) could all be threatened. In Cuba, invasions by $P$. monodon could affect the penaeid shrimp fishery, which is based on two species: pink shrimp $F$. notialis and white shrimp L. schmitti (Giménez-Hurtado et al., 2014). Although at present no diseases have been detected in captured $P$. monodon organisms, it is well-known that it is capable of spreading various viral diseases like monodon baculovirus (MBV), infectious hypodermal and hematopoietic necrosis virus (IHHNV), hepatopancreatic parvovirus (HPV), taura syndrome virus (TSV) (Lightner, 1996; Overstreet, Lightner, Hasson, Mcilwain, \& Lotz, 1997) that could affect local decapod species and other invertebrates (Aguado \& Sayegh, 2007). For these reasons, it is important to maintain continuous monitoring in the countries where this species is already established and those where the model indicates that potential invasions could occur. There are several preventive activities improved in different countries, like prohibit trade and possession of exotic species, prevent the escape of specimens on farms that grow exotic species, regulation and control of ballast water transport. Finally, it is important to consider that is better prevention than remediation both ecologically as well economically.

Ethical statement: the authors declare that they all agree with this publication and made significant contributions; that there is no conflict of interest of any kind; and that we followed all pertinent ethical and legal procedures and requirements. All financial sources are fully and clearly stated in the acknowledgements section. A signed document has been filed in the journal archives.

\section{RESUMEN}

Distribución potencial del camarón tigre Penaeus monodon (Decapoda: Penaeidae), una especie invasora en el Océano Atlántico. Introducción: Las especies invasoras son consideradas como la segunda causa de extinción de especies nativas después de la pérdida del hábitat. Los impactos de las especies invasivas tienen serias implicaciones económicas, ya que su presencia puede resultar en un decremento de los servicios ecosistémicos que benefician al hombre. En los sistemas marinos, algunas actividades humanas como el transporte marítimo y la acuicultura han favorecido la dispersión de especies invasivas, especialmente aquellas con importancia comercial. Este artículo describe la distribución potencial del camarón tigre, Penaeus monodon, una especie invasora a lo largo de la costa Atlántica Occidental. Objetivo: Describir un modelo de distribución potencial de Penaeus monodon en la región del Atlántico americano y comparar las características ambientales de esta región con las condiciones del nicho original del Indo-Pacífico. Metodología: Usando datos geográficos y ambientales, se generaron tres modelos para determinar la eficiencia del software MaxEnt v.3.3 en la predicción de nuevas áreas para la distribución de esta especie invasora. Los datos geográficos se descargaron de sitios web como el Fondo para la Información sobre la Biodiversidad Mundial, el Sistema de Información Biogeográfica del Océano y el Servicio Geológico de los Estados Unidos de América, así como de la literatura. Los datos ambientales fueron descargados de Bio-Oracle v2.0. Los tres modelos probados fueron: 1) registros de $P$. monodon de la región del Indo-Pacífico (zona de origen) 
y su proyección al Océano Atlántico (modelo nativo); 2) registros del área invadida, al utilizar el Océano Atlántico como área de entrenamiento y proyección del modelo (modelo invasivo); y 3) registros de las áreas Indo-Pacífico y Atlántico para capacitar y proyectar el modelo conjuntamente en ambas áreas (modelo completo). Extrajimos los valores de los tres modelos para cada avistamiento de camarones tigre en el área invadida; los avistamientos con valores $\geq 0.5$ fueron considerados como predicciones válidas de presencia de la especie. Resultados: Los resultados mostraron que las siguientes variables explicaron el $80 \%$ de la distribución de la especie: fosfatos del fondo marino, tipo de costa, clorofila $a$ y temperatura máxima del fondo. En términos de las capacidades de los modelos para predecir las presencias reportadas en el Atlántico, los resultados fueron los siguientes: modelo nativo, tuvo un índice de predicción del $40 \%$; modelo invasivo fue capaz de predecir el $81 \%$ de los registros; y modelo completo predijo el $92 \%$ de las ocurrencias totales reportadas en el área de invasión. Conclusiones: Se encontró que, con base en el modelo conjunto, los países donde el camarón tigre se podría establecer son México y Cuba. Esto sugiere que el monitoreo continuo y las acciones de conservación son relevantes en los países donde esta especie está actualmente establecida, así como en aquellos países con el potencial de ser invadidos.

Palabras clave: invasiones biológicas, predicción invasiva, nicho realizado, modelo de factores ambientales, modelación espacial.

\section{REFERENCES}

Aguado, N. F., \& Sayegh, J. (2007). Presencia del camarón tigre, Penaeus monodon, en la costa del Estado Anzoátegui, Venezuela. Boletín del Instituto Oceanográfico de Venezuela, 46(2), 107-111.

Alfaro-Montoya, J., Monge-Ortiz, A. M., Martínez-Fernández, D., \& Herrera-Quesada, E. (2015). First record of the nonindigenous Penaeus monodon Fabricius, 1798 (Penaeidae) in the Caribbean Sea of Costa Rica, Central America, with observations on selected aspects of its reproductive biology. Biolnvasions Records, 4(3), 217-222.

Altuve, D. E., Marcano, L. A., Alió, J. J., \& Blanco-Rambla, J. P. (2008). Presencia del camarón tigre Penaeus monodon (Fabricius, 1798) en la costa del delta del río Orinoco y golfo de Paria, Venezuela. Memoria de la Fundación La Salle de Ciencias Naturales, 68(169), 83-92.

Bax, N., Williamson, A., Agüero, M., González, E., \& Geeves, W. (2003). Marine invasive alien species: a threat to global biodiversity. Marine Policy, 27(4), 313-323.

Bock, D. G., Caseys, C., Cousens, R. D., Hahn, M. A., Heredia, S. M., Hübner, S., \& Rieseberg, L. H. (2015). What we still don't know about invasion genetics. Molecular Ecology, 24(9), 2277-2297.
Briggs, M., Funge-Smith, S., Subasinghe, R. P., \& Phillips, M. (2005). Introducciones y movimiento de dos especies de camarones peneidos en Asia y el Pacífico. Roma, ITA: Food \& Agriculture Org.

Broennimann, O., \& Guisan, A. (2008). Predicting current and future biological invasions: both native and invaded ranges matter. Biology Letters, 4(5), 585-589.

Broennimann, O., Fitzpatrick, M. C., Pearman, P. B., Petitpierre, B., Pellissier, L., Yoccoz, N. G., ... Guisan, A. (2012). Measuring ecological niche overlap from occurrence and spatial environmental data. Global Ecology and Biogeography, 21, 481-497.

Cawthorne, D. F., Beard, T., Davenport, J., \& Wickins, J. F. (1983). Responses of juvenile Penaeus monodon Fabricius to natural and artificial sea waters of low salinity. Aquaculture, 32(1-2), 165-174.

Cintra, I. H., De Sá Paiva, K., Do Nascimento Botelho, M., \& De Araújo Silva, K. C. (2011). Presence of Penaeus monodon in the continental shelf of the State of Para, Northern Brazil (Crustacea, Decapoda, Penaeidae). Amazonian Journal of Agricultural and Environmental Sciences, 54(3), 314-317.

Dall, W., Hill, B. J., Rothlisberg, P. C., \& Sharples, D. J. (1990). The biology of the Penaeidae (Advances in Marine Biology, 27). San Diego, CA: Academic Press.

Da Silva, J. M. C., De Souza, M. A., Ribeiro, V., \& Machado, R. B. (2018). Niche expansion of the common waxbill (Estrilda astrild) in its non-native range in Brazil. Biological Invasions, 20(9), 2635-2646.

Duncan, C. P., Schladow, S. G., \& Williams, W. G. (1982). Surface currents near the greater and lesser Antilles. International Hydrographic Review, 59(2), 67-78.

Elith, J., Phillips, S. J., Hastie, T., Dudík, M., Chee, Y. E., \& Yates, C. J. (2011). A statistical explanation of MaxEnt for ecologists. Diversity and Distributions, 17(1), 43-57.

FAO. (2018). Cultured Aquatic Species Information Programme. Penaeus monodon. Retrieved from http://www.fao.org/fishery/culturedspecies/ Penaeus monodon/en

Ficetola, G. F., Thuiller, W., \& Miaud, C. (2007). Prediction and validation of the potential global distribution of a problematic alien invasive species - the American bullfrog. Diversity and Distributions, 13(4), 476-485.

Flegel, T. W. (1997). Major viral diseases of the black tiger prawn (Penaeus monodon) in Thailand. World Journal of Microbiology and Biotechnology, 13(4), 433-442.

Giménez-Hurtado, E., Jar, L. P., Ceballos, B. J., Vilaon, D. C., Ramírez, J. R., \& Naranjo, R. A. (2014). Distribución del camarón tigre Penaeus monodon (Fabricius, 1798) en las costas de Cuba. Perspectivas y acciones futuras. Revista Cubana de Investigaciones Pesqueras, 31(1), 30-36. 
Guisan, A., Petitpierre, B., Broennimann, O., Daehler, C., \& Kueffer, C. (2014). Unifying niche shift studies: insights from biological invasions. Trends in Ecology \& Evolution, 29(5), 260-269.

Johnson, L. E., Ricciardi, A., \& Carlton, J. T. (2001). Overland dispersal of aquatic invasive species: a risk assessment of transient recreational boating. Ecological Applications, 11(6), 1789-1799.

Knott, D. M., Fuller, P. L., Benson, A. J., \& Neilson, M. E. (2018). Penaeus monodon: U.S. Geological Survey. Retrieved from https://nas.er.usgs.gov/queries/factsheet.aspx?SpeciesID=1209

Kulhanek, S. A., Leung, B., \& Ricciardi, A. (2011). Using ecological niche models to predict the abundance and impact of invasive species: application to the common carp. Ecological Applications, 21(1), 203-213.

Leroy, B., Delsol, R., Hugueny, B., Meynard, C.N., Barhoumi, C., Barbet-Massin, M., \& Bellard, C., (2018). Without quality presence - absence data, discrimination metrics such as TSS can be misleading measures of model performance. Journal of Biogeography, 45, 1994-2002.

Lightner, D. V. A. (1996). Handbook of shrimp pathologyand diagnostic procedures for disease of cultured penaeid shrimp. Baton Rouge, USA: World Aquaculture Society.

Lutz, Í., Nascimento, M., Isaac, V., Raiol, M., Silva, U., Mourão, K., \& Bentes, B. (2015). First record of giant-tiger-shrimp Penaeus monodon Fabricius, 1798, in an upper Amazon estuary. Biota Amazônia, 5(3), 115-116.

Morán-Silva, A., Chávez-López, R., Jiménez-Badillo, M., Cházaro-Olvera, S., Galindo-Cortes, G., \& MeinersMandujano, C. G. (2017). Análisis de la comunidad de peces de descarte en la pesca de arrastre de camarón (temporada de lluvias 2013) en la zona centro-sur del litoral veracruzano, México. Revista de Biología Marina y Oceanografia, 52(3), 551-566.

Overstreet, R., Lightner, D., Hasson, K., Mcilwain, S., \& Lotz, J. (1997). Susceptibility to Taura syndrome virus of some penaeid shrimp species native to the Gulf of Mexico and the southeastern United States. Journal of Invertebrate Pathology, 69, 165-176.

Peterson, A. T., \& Vieglais, D. A. (2001). Predicting Species Invasions Using Ecological Niche Modeling: New Approaches from Bioinformatics Attack a Pressing Problem: A new approach to ecological niche modeling, based on new tools drawn from biodiversity informatics, is applied to the challenge of predicting potential species' invasions. BioScience, 51(5), 363-371.

Phillips, S. J., Anderson, R. P., \& Schapire, R. E. (2006) Maximum entropy modeling of species geographic distributions. Ecological Modelling, 190(3-4), 231-259.
R Core Team. (2018). R: A language and environment for statistical computing. R Foundation for Statistical Computing. Vienna, Austria. Retrieved from https:// www.R-project.org

Rodríguez, G., \& Suárez, H. (2001). Anthropogenic dispersal of decapod crustaceans in aquatic environments. Interciencia, 26(7), 282-288.

Sandoval, L. A., Leal-Florez, J., Taborda, A., \& Vásquez, J. G. (2014). Spatial distribution and abundance of the giant tiger prawn, Penaeus monodon (Fabricius, 1798), in the Gulf of Urabá (Caribbean), Colombia, South America. BioInvasions Records, 3(3), 169-173.

Schoener, T. W. (1968). Anolis lizards of Bimini: resource partitioning in a complex fauna. Ecology, 49, 704-726.

Simberloff, D., Parker, I. M., \& Windle, P. N. (2005). Introduced species policy, management, and future research needs. Frontiers in Ecology and the Environment, 3(1), 12-20.

Soberón, J., \& Peterson, A. T. (2005). Interpretation of models of fundamental ecological niches and species distributional areas. Biodiversity Informatics, 2, 1-10.

Thuiller, W., Richardson, D. M., Pyšek, P., Midgley, G. F., Hughes, G. O., \& Rouget, M. (2005). Niche $\square$ based modelling as a tool for predicting the risk of alien plant invasions at a global scale. Global Change Biology, 11(12), 2234-2250.

Tingley, R., Vallinoto, M., Sequeira, F., \& Kearney, M. R. (2014). Realized niche shift during a global biological invasion. Proceedings of the National Academy of Sciences, 111(28), 10233-10238.

Turner, K. G., Fréville, H., \& Rieseberg, L. H. (2015). Adaptive plasticity and niche expansion in an invasive thistle. Ecology and Evolution, 5(15), 3183-3197.

Wakida-Kusunoki, A. T., De Anda-Fuentes, D., \& LópezTéllez, N. A. (2013). Presence of giant tiger shrimp Penaeus monodon (Fabricius, 1798) in eastern Peninsula of Yucatan coast, Mexico. Latin American Journal of Aquatic Research, 44(1),155-158.

Wakida-Kusunoki, A. T., Rojas-González, R. I., GonzálezCruz, A., Amador del Ángel, L. E., Sánchez-Cruz, J. L., \& López-Tellez, N. A. (2016). Presence of giant tiger shrimp Penaeus monodon Fabricius, 1798 on the Mexican coast of the Gulf of Mexico. BioInvasions Records, 2(4), 325-328.

Warren, D. L., Glor, R. E., \& Turelli, M. (2008). Environmental niche equivalency versus conservatism: quantitative approaches to niche evolution. Evolution: International Journal of Organic Evolution, 62(11), 2868-2883. 